\title{
SISTEM MASTER PLAN SMART CITY KABUPATEN BANYUMAS
}

\author{
Sigit Rizaldi*1 $^{*}$, Arief Kelik Nugroho ${ }^{2}$ \\ 1,2Jurusan Informatika, Fakultas Teknik, Universitas Jenderal Soedirman

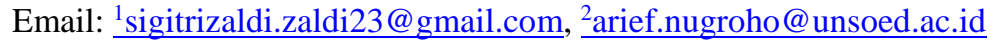

(Naskah masuk: 25 Juni 2020, diterima untuk diterbitkan: 17 Juli 2020)

\begin{abstract}
Abstrak
Dinas Komunikasi dan Informatika (DINKOMINFO) Banyumas adalah sebuah instansi yang bertanggung jawab atas pengolahan informasi dalam lingkungan Pemerintahan Banyumas. Pada tahun 2017, Kementrian Kominfo bekerja sama dengan kementrian lain untuk menginisiasi gerakan menuju 100 smart city atau mendorong terciptanya 100 kota cerdas pada tahun 2019. Kabupaten Banyumas terpilih dari salah satu diantara 25 Kota untuk menjadi plot project smart city. Kabupaten Banyumas melakukan akselerasi pembangunan dengan konsep pemanfaatan teknologi untuk mengembangkan smart city Banyumas. Dengan adanya hal tersebut DINKOMINFO menginginkan sebuat aplikasi yang dapat mendorong pengembangan smart city yang efektif, efisien, dan partisipatif serta sebagai bagian dari perencanaan operasional, yang disebut dengan master plan smart city. Pengembangan sistem yang dilakukan menggunakan metode kanban, dengan alat yang digunakan adalah papan kanban (Kanban Board). Hasil dari penelitian ini adalah memberikan informasi mengenai data data yang masuk di sistem master plan smart city dan dapat mendorong pengembangan smart city yang efektif, efisien, dan partisipatif serta sebagai bagian perencanaan operasional.
\end{abstract}

Kata kunci: Banyumas, kanban, master plan, smart city.

\section{SYSTEM OF MASTER PLAN SMART CITY BANYUMAS DISTRICT}

\begin{abstract}
The Banyumas Communication and Information Office (DINKOMINFO) is an agency responsible for processing information in the Banyumas Government environment. In 2017, the Ministry of Communication and Information in collaboration with other ministries to initiate a movement towards 100 smart cities or encourage the creation of 100 smart cities in 2019. Banyumas Regency was chosen from one of 25 cities to become a smart city plot project. Banyumas Regency accelerates development with the concept of utilizing technology to develop Banyumas smart cities. With this, DINKOMINFO wants an application that can encourage the development of smart cities that are effective, efficient, and participatory and as part of operational planning, which is called the smart city master plan. System development is carried out using the kanban method, with the tool used is the kanban board. The results of this study are to provide information about the data entered in the smart city master plan system and can encourage the development of smart cities that are effective, efficient, and participatory and as part of operational planning.
\end{abstract}

Keywords: Banyumas, kanban, master plan, smart city.

\section{PENDAHULUAN}

\subsection{Latar Belakang}

Perkembangan teknologi informasi dalam penyelenggaraan pemerintahan dan pelayanan publik mendorong negara untuk membentuk peradaban baru yang menerapkan digitalisasi sebagai bentuk modernitas pemerintahan dalam pelayanan publik yang lebih cerdas. Negara cerdas terbentuk dengan mengimplementasikan konsep smart city pada kota - kotanya, yaitu suatu konsep wilayah kota yang telah mengintegrasikan teknologi informasi dan komunikasi dalam tata kelola sehari hari, dengan tujuan untuk mempertinggi efisiensi, memperbaiki pelayanan publik, dan meningkatkan kesejahteraan warga. 
Dalam rangka mengembangkan smart city atau mendorong terciptanya 100 kota cerdas pada tahun 2019. Meski demikian, implementasi smart city di Indonesia tidaklah muda dan mengalami berbagai tantangan, mulai dari infrastruktur penunjang yang belum memadai, hingga masyarakat sendiri yang belum mampu memanfaatkan teknologi digital secara maksimal

Pada tahun 2019, Kabupaten Banyumas terpilih dari salah satu diantara 25 kota untuk menjadi pilot project smart city. Sebagai bentuk komitmen pemerintah daerah dalam mendukung pembangunan nasioal untuk mewujudkan smart nation yang dirangkai dari samrt city maka Kabupaten Bnayumas melakukan akselerasi pembangunan dengan konsep pemanfaatan teknologi informasi untuk mengembangkan smart city Banyumas.

Dimensi smart city Banyumas menjadi prioritas perubahan meliputi tata kelola birokrasi (smart governance), pemasaran daerah (smart branding), perekonomian (smart economy), ekosistem permukiman penduduk (smart living), lingkungan masyarakat (smart society), dan pemeliharaan lingkungan (smart environment). Dinas Komunikasi dan Informatika Kabupaten Banyumas (DINKOMINFO) berkeinginan agar terdapat aplikasi yang dapat mendorong pengembangan smart city yang efektif, efisien, dan partisipatif serta sebagai bagian perencanaan operasional, yang disebut dengan master plan smart city. Dari uraian di atas, permasalahann yang dapat diselesaikan dengan membuat suatu sistem berbasis web yang dapat membantu dalam perencanaan operasional sistem smart city Banyumas dan dapat mendorong pengembangan smart city secara efektif dan efisien.

\subsection{Rumusan Masalah}

Permasalahan yang ada diantaranya adalah :

a. DINKOMINFO belum memiliki sistem Master Plan Smart City berbasis website

b. Bagaimana membuat pengelolaan data smart city menggunakan sistem master plan?

c. Bagaimana membuat sistem tersebut sesuai dengan rancangan yang telah dibuat?

\subsection{Batasan Masalah}

Batasan masalah dalam "Sistem Master Plan

Smart City Kabupaten Banyumas" antara lain:

a. Sistem yang dibuat merupakan perangkat lunak berbasis website.

b. Pihak yang menggunakan sistem ini adalah DINKOMINFO Banyumas sebagai admin dalam mengelola data smart city di sistem master plan c. User pengunjunjung hanya dapat melihat data yang masuk di sistem master plan.

\subsection{Tinjauan Pustaka}

a. Master Plan

Master Plan adalah suatu perencanaan jangka menengah dalam pengembangan sistem informasi di suatu organisasi, yang dengan baik bisa menterjemahkan keinginan baik dari manajemen, pengguna, maupun perubahan - perubahan yang terjadi di dalam maupun di luar organisasi [1]-[3].

b. Laravel

Laravel adalah sebuah Framework PHP dirilis dibawah lisensi MIT dengan kode sumber yang sudah disediakan oleh Github. Sama seperti framework-framework yang lain, Laravel dibangun dengan konsep MVC (Model-Controller-View). Laravel dilengkapi juga command line tool yang bernama "Artisan" yang bisa digunakan untuk packaging bundle dan instalasi bundle melalui command prompt [4]-[6].

c. Basis Data

Basis dapat diartikan sebagai markas atau gudang, tempat bersarang/berkumpul. Sedangkan Data adalah representasi fakta dunia nyata yang mewakili suatu objek seperti manusia (pegawai, siswa, pembeli, pelanggan), barang, hewan, peristiwa, konsep, keadaan, dan sebagainya, yang diwudujkan dalam bentuk angka, huruf, simbol, teks, gambar, bunyi, atau kombinasinya [7]-[9].

d. Sistem

Sistem adalah suatu jaringan kerja dari prosedur - prosedur yang saling berhubungan, berkumpul bersama - sama untuk melakukan suatu kegiatan atau menyelesaikan suatu sasaran yang tertentu [10].

e. Smart City

Smart City merupakan suatu konsep pengembangan, penerapan, dan implementasi teknologi yang diterapkan untuk wilayah (khususnya perkotaan) sebagai sebuah interaksi yang kompleks di antara berbagai sistem yang ada di dalammya [11].

\section{f. Framework}

Framework adalah kerangka kode yang dapat disempurnakan dengan kelasm- kelas yang spesifik atau dengan fungsi yang telah dirancang untuk mengatasi masalah yang dihadapi [12],[13].

g. Rancang Bangun

Rancang bangun adalah proses menterjemahkan hasil analisa dari sebuah sistem untuk menguraikan bagaimana elemen - elemen sistem siap diterapkan dengan tujuan untuk menciptakan sistem baru, maupun dengan memperbaiki sistem yang sudah ada [14]-[16]. 


\section{METODE PENELITIAN}

\subsection{Pengumpulan Data}

Pengumpulan data yang dilakukan dengan menggunakan metode diskusi. Metode diskusi merupakan metode pengumpulan data yang dapat melibatkan beberapa individual atau user dengan kepentingan yang sama. Tujuan dengan adanya diskusi ini untuk menambahkan pengetahuan secara kolektif terhadap semua anggota tim.

Diskusi yang kami lakukan memiliki dua arah. Pertama pada satu waktu pihak DINKOMINFO Banyumas melakukan presentasi untuk memimpin diskusi. Diskusi yang yang kedua kami yang memimpin untuk melakukan presentasi tentang perkembangan kegiatan yang telah dibuat yang diberikan untuk pihak DINKOMINFO Banyumas.

\subsection{Analisis Data}

Data yang telah dikumpulkan dalam diskusi kemudia dilakukan analisis bersama anggota tim lain. Informasi yang diperlukan dari tahap analisis adalah sebagai berikut:

a. Lingkup Aplikasi

Lingkup aplikasi mengacu pada fitur - fitur yang akan dikerjakan selama proyek. Beberapa poin informasi yang didapat berupa tugas (backlog), prioritas backlog, rencana sprint, dan kebutuhan pendukung lainnya.

b. Waktu

Analisi waktu mengacu pada jumlah waktu yang dibutuhkan untuk menyelesaikan suatu tugas per - iterasi.

c. Kualitas

Analisis kualitas mengacu pada kebijakan yang diperlukan untuk menjaga kualitas produk dan mencegah dari kekacauan atau pelanggaran sistem kanban.

\subsection{Visualisasi alur kerja}

Memvisualisasikan setiap langkah kerja, dari ide yang tidak jelas hingga perangkat lunak yang siap dirilis pada papan kanban. Pada tahap ini dilakukan iterasi sejak pengumpulan data, analisis, pengembangan, testing dan rilis untuk tugas. Kami menggunakan aplikasi Kanban Flow sebagai papan Kanban.

\subsection{Membuat Batas Status Kerja}

Membuat batas maksimal tugas yang diperoleh pada satu kolom status kerja. Batas ini dituliskan pada papan Kanban dan secara prinsip setiap anggota tim harus mematuhinya.

\subsection{Mengelola alur kerja}

Prinsip mengelola aliran kerja adalah menjaga fokus pada tugas yang ada. Pada beberapa praktiknya, untuk menjaga kekonsistensian alur kerja adalah dengan memastikan semua tugas yang diperlukan dalam pengembangan aplikasi tercantum pada Kanban board dan mengerjakan proses yang hanya terdapat pada Kanban board saja sampai proses tersebut benar-benar selesai.

\subsection{Perbaiki}

Proses perbaikan dilakukan setelah proses atau fungsi yang telah dibuat dirasa selesai. Sebelum proses ini dijalankan, perlu dilakukan pengiriminan fungsionalitas kepada client terlebih dahulu, apakah hal tersebut sudah sesuai dengan yang diinginkan atau belum. Jika belum, maka proses tersebut masuk kedalam tahap perbaikan sampai memenuhi keinginan client namun tetap dengan perjanjian yang berlaku.

\section{HASIL DAN PEMBAHASAN}

\subsection{Visualisasi Alur Kerja}

Padah tahap ini kami melakukan pendefinisian alur kerja dan setiap tugas yang dilakukan atau backlog yang diperlukan untuk membuat suatu sistem pada sebuah papan kanban atau aplikasi yang memiliki satu fungsi dengan papan kanban. Visualisasi alur kerja termasuk di dalamnya terdapat iterasi untuk analisis, pengkodean dan testing setiap backlog yang ada. Backlog dapat bertambah atau berkurag dengan berbagai sebab.

\subsection{Cerita Pengguna (User Story)}

Cerita pengguna ini digunakan untuk mendeskripsikan apa saja yang diinginkan oleh pengguna. Cerita pengguna ini mendasari sebuah fitur dalam aplikasi dan tugas dalam papan Kanban, namun tidak semua tugas merupakan bagian dari dari cerita pengguna.

Penulis didalam cerita pengguna ini dengan cara melakukan sebuah grup diskusi dengan pembimbing lapangan, pegawai DINKOMINFO Banyumas, dan teman satu tempat kerja praktik. Berikut rincian cerita pengguna pada tabel 1 . dibawah ini.

\subsection{Tugas (Backlog)}

Backlog adalah sekumpulan user story atau tugas. User story yang dijadikan backlog dipastikan 
terlebih dahulu tidak bertentangan terkait fitur yang diinginkan. Tugas dapat berasal dari hasil iterasi semisal mendapatkan bug pada suatu fitur. Tabel user stories di atas telah memenuhi kriteria sebagai tugas karena tidak bertentangan.

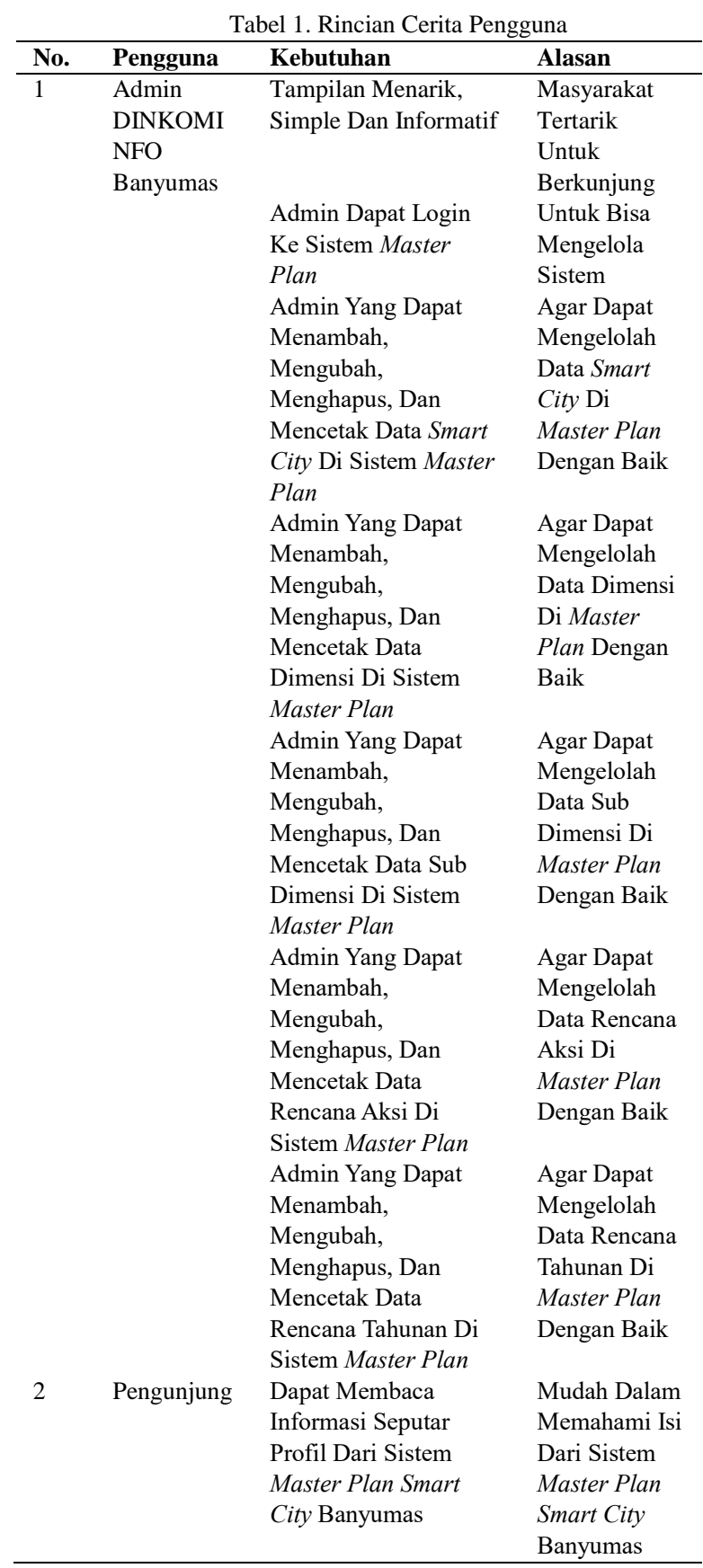

\subsection{Papan Kanban (Kanban Board)}

Papan Kanban dibuat setelah menentukan tugas yang yang diberikan (Backlog), dalam hal ini backlog mungkin bisa saja bertambah, berkurang, atau berubah kapan saja. Jadi penulis menggunakan papan Kanban melalui aplikasi berbasis website di laman https://kanbanflow.com/.

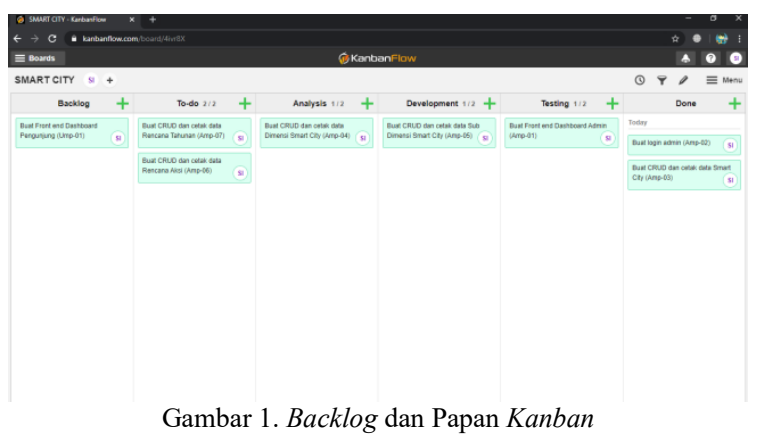

\subsection{Analisis dan Desain}

Pada tahap analisis dan desain aplikasi, kami menggunakan UML (Unified Modeling Language) yang cocok untuk pengembangan aplikasi berorientasi objek. Tahap analisis dan desain dibagi menjadi beberapa hasil rancangan sebagai berikut:

\section{a. Use Case Diagram}

Use Case Diagram menjelaskan interaksi yang ada antara sistem dengan aktor yang berperan dalam sistem. Berikut ini adalah Use Case Diagram dari Sistem Master Plan Smart City Kabupaten Banyumas.

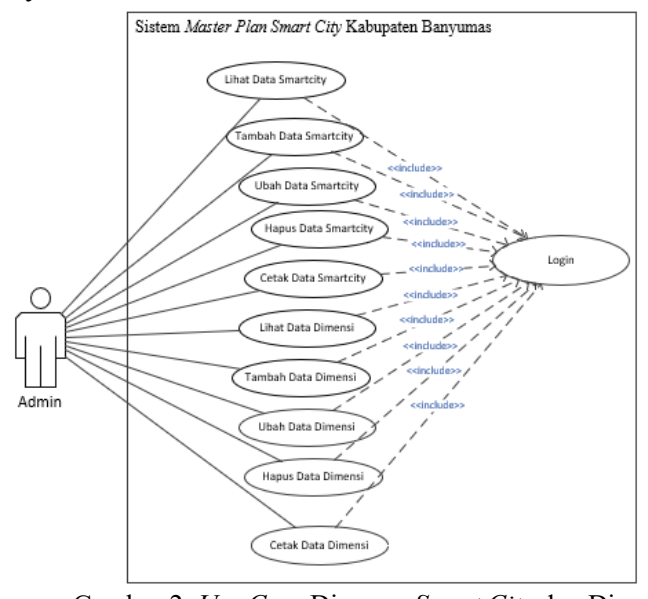

Gambar 2. Use Case Diagram Smart City dan Dimensi

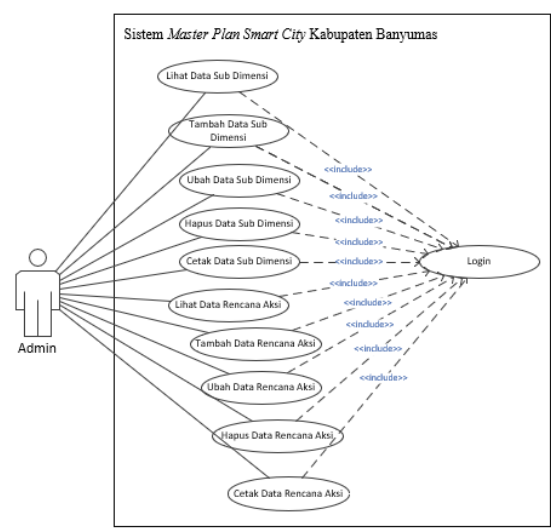

Gambar 3. Use Case Diagram Sub Dimensi dan Rencana Aksi 
Gambar 2 menjelaskan interaksi yang dapat dilakukan oleh Admin melakukan crud pada data Smart City dan data Dimensi pada sistem.

Gambar 3 menjelaskan interaksi yang dapat dilakukan oleh Admin melakukan crud pada data Sub Dimensi dan data Rencana Aksi pada sistem.

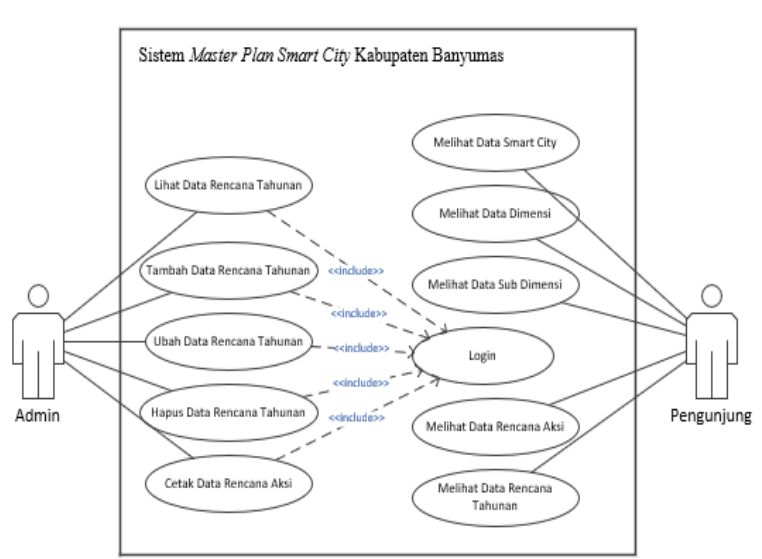

Gambar 4. Use Case Diagram Rencana Tahunan dan Pengunjung

Gambar 4 menjelaskan interaksi - interaksi yang dapat dilakukan oleh Admin dan Pengunjung, dimana admin melakukan crud pada data Rencana Tahunan dan Pengunjung hanya dapat melihat data - data pada sistem.

\section{b. Class Diagram}

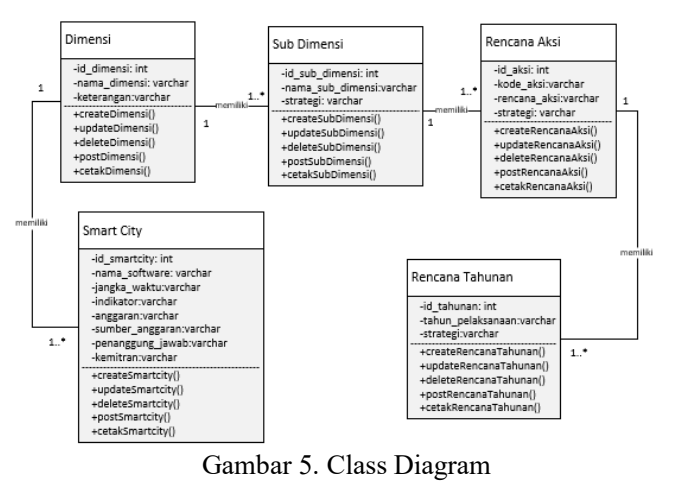

Gambar 5. menjelaskan tentang Class Diagram yang saling berelasi di dalam Master Plan Smart City Banyumas.

\section{c. Desain Antar Muka}

Gambar 6. merupakan desain antarmuka dari halaman Dashboard Admin, dimana pada halaman ini memiliki akses penuh untuk admin.
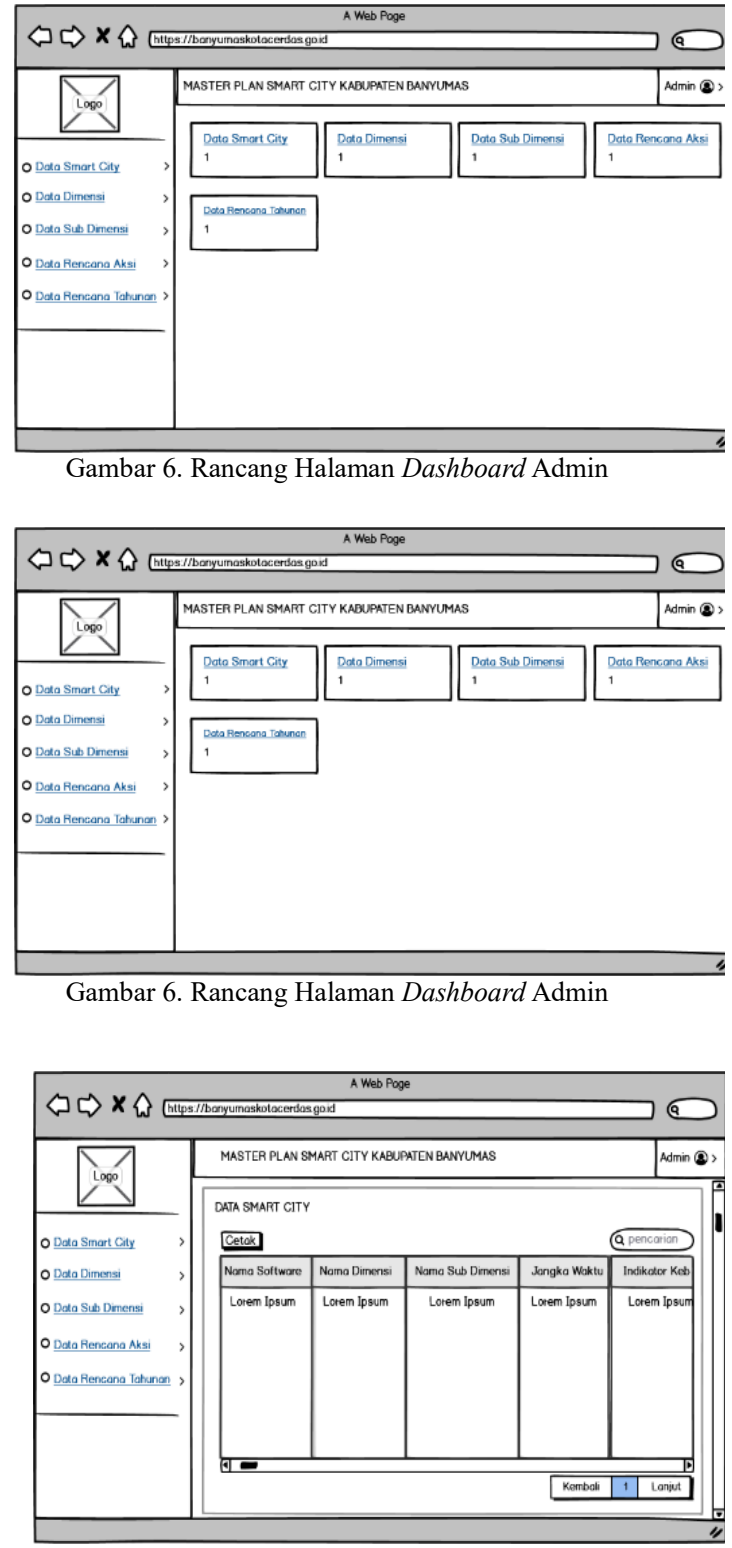

Gambar 7. Rancang Halaman Smart City Admin

Gambar 7 merupakan desain antarmuka dari halaman Smart City, dimana pada halaman ini admin dapat melakukan pengolahan data (crud) didalamnya.

\subsection{Tahap Konstruksi (Development)}

Pada tahap konstruksi akan dilakukan perancangan bentuk antarmuka (interface) dari sistem yang akan dikembangkan, dengan berdasar pada alur sistem, perancangan dan desain yang telah dilakukan pada tahap sebelumnya. 


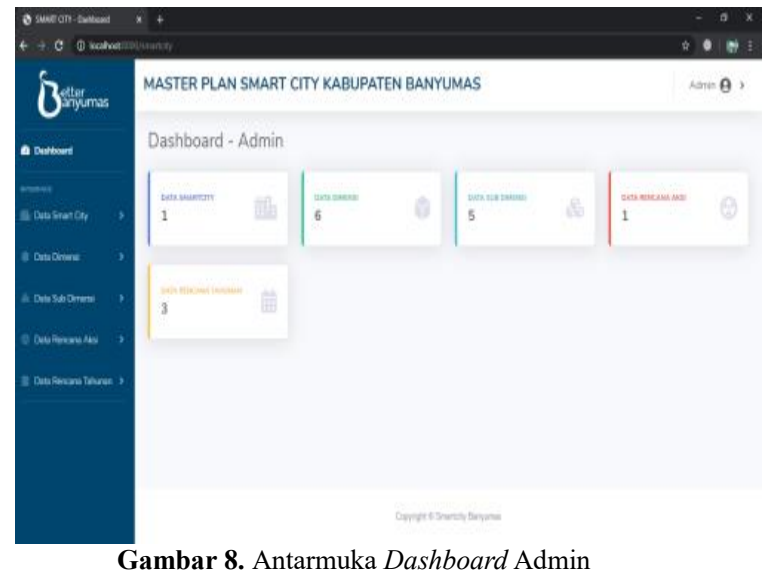

Pada admin, setelah melakukan proses login, user akan dialihkan ke halaman dashboard. Pada halaman ini, terdapat informasi mengenai jumlah data yang sudah terisi disetiap tabelnya, dan dapat melakukan pengolahan data didalamnya.

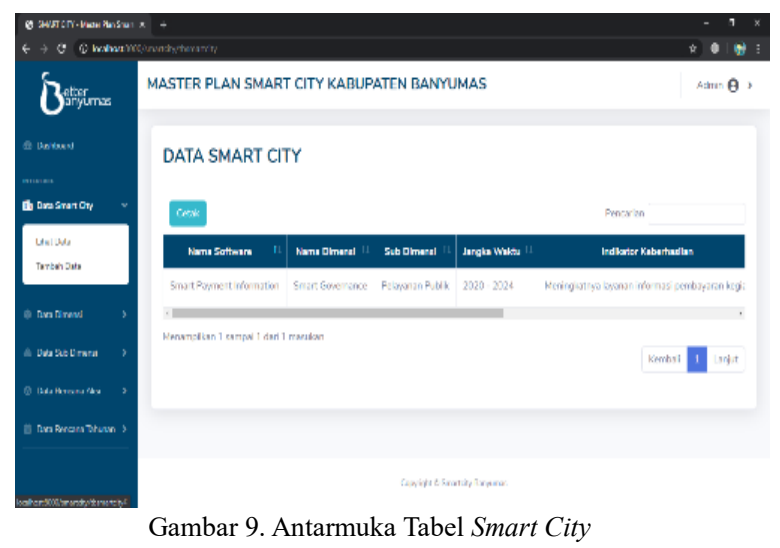

Pada halaman ini, admin dapat melakukan proses crud dan cetak pada table Smart City.

\subsection{Membatasi Proses Kerja (Limit Work-In- Process)}

Dalam melakukan proses kerja praktik, membuat sistem Master Plan Smart City Banyumas, kami melakukan pembatasan proses kerja. Pembatasan tersebut berupa angka kecil yang berada di kolom kerja papan Kanban. Pembatasan proses kerja berguna untuk membatasi jumlah kerja yang akan dilakukan dan merupakan suatu aturan kerja yang harus ditaati.

\subsection{Mengelola Alur (Managing Flow)}

Prinsip mengelola aliran kerja adalah dengan menjaga fokus terhadap tugas yang ada. Beberapa praktik yang diterapkan untuk menjaga konsistensi yaitu dengan memastikan semua tugas yang diperlukan dalam pengembangan sistem Master Plan Smart City Banyumas yang tersedia di papan
Kanban, mengerjakan hanya apa yang dilihat, senantiasa disiplin dan menuntaskan tugas secara tuntas, dan melalukan presentasi, ketika pekerjaan tersebut sudah selesai dilaksanakan.

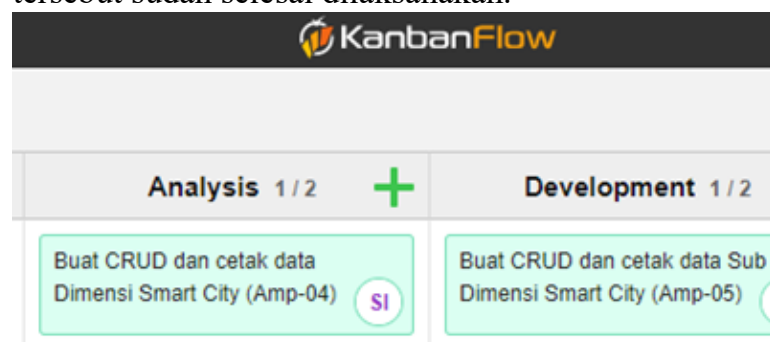

Gambar 10. Pembatasan Kerja di Papan Kanban

\section{KESIMPULAN}

Berdasarkan ide gagasan Sistem Master Plan Smart City Kabupaten Banyumas yang telah dijabarkan, maka dapat disimpulkan bahwa upaya yang dapat dilakukan guna mengefisiensikan proses penginputan data smart city ke dalam Master Plan smart city Kabupaten Banyums dapat dilakukan dengan cara memanfaatkan peran teknologi, salah satunya dengan adanya Sistem Informasi atau aplikasi.

Dengan merancang dan membangun Sistem Mater Plan Smart City Kabupaten Banyumas berbasis website dapat mengefektifkan dan memudahkan proses pengolahan data smart city ke dalam Master Plan smart city Kabupaten Banyumas dan data tersebut dapat dicetak untuk digunakan sebagai bahan laporan untuk DINKOMINFO Kabupaten Banyumas.

\section{DAFTAR PUSTAKA}

[1] Aminudin.2015. Cara Efektif Belajar Framework Laravel. Yogyakarta: Lokomedia.

[2] Fathansyah.2015.Basis Data Revisi Kedua. Bandung: INFORMATIKA.

[3] Jogiyanto, H.2015. Analisa dan Desain Sistem Informasi. Yogyakarta: ANDI.

[4] Pratama..2014. Smart City Beserta Cloud Computing Dan Teknologi - Teknologi Pendukung. Bandung: INFORMATIKA.

[5] Pressman, P. R. 2010. Pendekatan Praktisi Rekayasa Perangkat Lunak. Yogyakarta: Andi.

[6] Pressman, R. S. 2012. Rekayasa Perangkat Lunak (Edisi 7). Yogyakarta: ANDI.

[7] A.K. Nugroho, D. Iskandar, "Algoritma Iterative Dichotomizer 3 (ID3) Pengambilan Keputusan", Jurnal Dinamika Rekayasa. (DINAREK).2015.

[8] A.K. Nugroho I. Permadi,"Ant Colony Optimization Untuk Menyeleksi Fitur Dan Klasifikasi Artikel”. Jurnal SIMETRIS: Vol. 10 No. 1.2019. 
[9] A.K. Nugroho, I. Permadi, Nofiyati and S.R Hayu ,"Sistem Pendukung Keputusan Penilaian Kesehatan Tanah Dengan Metode Simple Additive Weighting" Jurnal Pengembangan IT (JPIT): Vol.04, No.01.2019.

[10] A.K Nugroho, I. Permadi., A. Hanifa,’Sistem Pendukung Keputusan Perekomendasian Oli Menggunakan Fuzzy MADM", JANAPATI.2020

[11] A.K. Nugroho, "Image Quantization In Psoriasis Using K-Mean Clustering",Prosiding Senatik STTA Adi Sucipto. Vol. IV.2018.

[12] A.K. Nugroho, I. Permadi, and A. Hanifa" Probabilistic Ant Colony Optimization for Contour Detection of Psoriasis".Proceeding in International Conference on Science and Engineering, 3, 179-182.2020

[13] A.K. Nugroho,I. Permadi, and A. Hanifa," Sistem Pendukung Keputusan Perekomendasian Oli Menggunakan Fuzzy MADM", Janapati Undiksa. Vol 9, No 1.2020

[14] A.K. Nugroho, Nofiyati And N. Chasanah,'Desain Sistem Pakar Diagnosis Penyakit Mata Sebagai Penunjang Pemeriksaan Gangguan Penglihatan”. Prosiding Seminar Nasional LPPM Unsoed. Vol.7 No.1.2017

[15] A. K.Nugroho, "Aplikasi Sig Untuk Evaluasi Sistem Jaringan Drainase Sub Das Gajahwong Kabupaten Bantul".Prosiding Seminar Nasional infomatika (Semnasif) UPN Yogyakarta.2013

[16] Y. I. Kurniawan and W. Dwiyatmika, "Aplikasi Diagnosa Retardasi Mental Pada Anak." in Seminar Nasional Psikologi UMS, 2017. 